\title{
Resources Sustainability. N Application in Crops to Determine the Best Environmental Performance Using Life Cycle Assessment Methodology
}

\author{
Roberto Quirós (Corresponding author) \\ Universidad de Costa Rica, Escuela de Ingeniería Industrial, San José, Costa Rica \\ Sostenipra Research Group, Sostenipra, Sostenibilitat i Prevenció Ambiental \\ ICTA (UAB) - IRTA - INEDIT, Barcelona, Spain \\ Tel: 506-2511-6638Ｅ-mail: roberto.quiros_v@ucr.ac.cr
}

Pere Muñoz

Sostenipra Research Group, Sostenipra, Sostenibilitat i Prevenció Ambiental ICTA (UAB) - IRTA - INEDIT, Barcelona, Spain

Institute of Research into the Agrifood Sector (IRTA), Environmental Horticulture

Ctra. de Cabrils s/n, 08348 Cabrils, Barcelona, Spain

Received: June 25, 2019 Accepted: July 12, 2019 Published: August 16, 2019

doi:10.5296/emsd.v8i3.15277～URL: https://doi.org/10.5296/emsd.v8i3.15277

\begin{abstract}
The use of mineral fertilizer in horticultural crops is a very important issue due to its effects on crop yield and its environmental impact. For the period 2011-2012, the total mineral fertilizer consumption in EU-27 reached 10.4 million tons of nitrogen $(\mathrm{N}), 1.0$ million tons of phosphorus $(\mathrm{K})$ and 2.2 million tons of potassium $(\mathrm{K})$. Though many recent studies have examined horticultural crops, few have focused on mineral fertilizers in order to make an environmental assessment of a tomato crop. Therefore, the aim of this research was to study the agronomical (i.e. yield) and the environmental performance of a horticultural tomato crop fertilized with four different doses of mineral fertilizer (N0, N1, N2 and N3), using Life Cycle Assessment methodology. Data and conditions for the crop were taken from a real field trial with an experimental design carried out in North-east Catalonia, Spain. Following the guidelines of the ISO 14044, the study considered all stages of the life cycle of a horticultural
\end{abstract}


tomato crop (i.e. mineral fertilizer production, transport and cultivation phase). Six impact categories were included in the study: climate change, photochemical oxidation formation, land acidification, freshwater and marine eutrophication and fossil depletion. Overall, the results showed that the best result was for the N1 treatment, with a yield of 61 ton ha ${ }^{-1}$ and 55 ton $\mathrm{ha}^{-1}$ for total and commercial yield, respectively. N1 showed the best environmental performance in all categories assessed.

Keywords: Sustainability, Life cycle assessment, Mineral fertilizers, Crop, Nitrogen

\section{Introduction}

Agricultural and horticultural crop production means ensuring sufficient income for growers and producing high-quality products in sufficient quantities at affordable prices, while at the same time being environmentally benign (Bentrup, 2012). This represents an increasing challenge, because a growing world population will demand increases in food production from limited agricultural areas (FAO, 2003).

Pollutants associated with excessive use of nitrogen $(\mathrm{N})$ fertilizer in intensive agriculture have increased in recent decades. Manufactured fertilizers have been increasingly used in regular farming practice in Europe since their introduction in the mid-to-late nineteenth century (Quirós et al., 2014a). In 2012, mineral fertilizer consumption in the EU was 13.4 million tons (Eurostat, 2016). Although fertilizers are very important in achieving greater crop yield, they represent a serious risk of pollution for the environment. Fertilizers are essential to sustaining agricultural production, increasing the yield and improving soil characteristics. However, when the quantity of the nutrients applied exceeds the plant's nutritional requirements, the risk of nutrient losses from agricultural soils into ground and surface water increases. The resulting higher concentration of nutrients can severely deplete ecosystems (causing, for example, eutrophication and acidification). Some forms of nitrogen (N) can also volatilize into the air as ammonia, contributing to acidification, atmospheric pollution with micro-particles or emissions of nitric oxide $\left(\mathrm{NO}_{\mathrm{x}}\right)$ and nitrous oxide $\left(\mathrm{N}_{2} \mathrm{O}\right)$, a greenhouse gas that contributes to climate change. In addition, the production process of fertilizers may also have adverse environmental effects. Energy use and losses of nitrogen compounds to the environment contribute to several environmental problems, such as eutrophication, acidification and climate change.

Fertirrigation, a technique used to apply to crops fertilizers dissolved in water (CREA, 2005), is a common practice in the Mediterranean region. It involves excessive nutrient usage, contributing to groundwater pollution and eutrophication (Muñoz et al., 2008). In analyzing the environmental consequences of mineral fertilizers, we need to distinguish between the impact of their industrial production technology and the impact of their application to agro-ecosystems (Skowroñska and Filipek, 2013).

The environmental impact of $\mathrm{N}$-use in agriculture has been analyzed in several research papers. Generally, these studies focused on individual effects such as nitrate leaching or ammonia volatilization (e.g. Bach and Becker, 1995; ECETOC, 1988, 1994; Engels, 1993; Sommer, 1992). However, agricultural production systems contribute to a wide range of 
environmental effects (e.g. climate change, acidification, eutrophication etc.) (Bentrup et al., 2004). Nitrogen fertilization affects yield and quality traits for processing, such as total solids, soluble solids, reducing sugars, acidity (Iqbal et al., 2011; Parisi, 2006; Kaniszewski et al., 1987; Kooner and Randhawa, 1990; Dadomo et al., 1994; Colla et al., 2003), with sometimes contradictory results between authors. The analysis of individual effects does not permit an overall conclusion in environmental terms, i.e. preference for one or another agricultural strategy. Therefore, the aim of this study is to focus on the agricultural (i.e. yield and quality) and environmental performance of a tomato crop. Tomatoes are the second most important fruit or vegetable in the world after potatoes. The crop is an excellent source of compounds that are beneficial to health, due to its balanced mixture of minerals and anti-oxidants. These include vitamins $\mathrm{C}$ and $\mathrm{E}$, lycopene, b-carotene, lutein and flavonoids such as quercetin (Dorais et al., 2008). One of the most important horticultural crops in the European Union (EU), tomatoes use a large amount of nitrogen. The EU-28 produced an estimated 16.8 million tons of tomatoes in 2014, of which approximately two-thirds came from Italy and Spain (Eurostat, 2016). Here, Life Cycle Assessment (LCA) methodology was used to study the environmental impact resulting from the application of several quantities of $\mathrm{N}$ to a tomato crop. LCA provides a methodology to investigate environmental impact in a holistic perspective. The LCA method proposed analyzes thoroughly all the environmental effects of arable farming practice (Bentrup et al., 2004). For crop production this means covering the wide range of different environmental effects and including all the various activities involved, ranging from fertilizer production to tractor use in the field (Bentrup, 2012). No similar LCA studies of the effect of $\mathrm{N}$ on a tomato crop have been found in the literature.

The aim of this study is to assess quantitatively the environmental and agricultural performance of a tomato crop fertilized with four fertilization treatments with different doses of $\mathrm{N}$ (N0, N1, N2 and N3). The tomato plants tested were of the 'Penjar' variety, which yields small tomatoes with a long shelf life that are very popular and widely consumed along the Spanish Mediterranean coast (Castellari, 2016). The tomatoes were grown in sandy loam. The soil was Typic Xerothent and exposed to the Mediterranean climate with annual evapotranspiration (ET0) and rainfall of 955 and $618 \mathrm{~mm}$, respectively. We used Life Cycle Assessment (LCA) to measure burdens such as mineral extraction, production, soil enrichment and transport.

\section{Methodology}

This section has been split into two main parts: a brief explanation of LCA methodology and its main steps in our case study; and the experimental methodology used.

\subsection{Life Cycle Assessment and Impact Categories}

According to ISO 14044 (ISO 2006), Life Cycle Assessment (LCA) is a method to assess the entire environmental impact of a product, process or activity by measuring and evaluating resource consumption and emissions. LCA is divided into four steps, which are (1) goal and scope definition, (2) inventory analysis, (3) impact assessment and (4) interpretation. In this study, we used LCA methodology to compare the environmental impact of four different doses of $\mathrm{N}$ applied to a tomato crop. LCA studies environmental and potential impact 
throughout a product's life (i.e. from cradle to grave). This involves raw material acquisition and production (i.e. mineral fertilizers, tools, machinery, pesticides, etc.), their applications to the crop and waste management (i.e. disposal). This LCA followed ISO 14044. The SimaPro v.7.3.3 Software Faculty version (Pré Consultant, 2016) was employed to calculate the impact, with the obligatory classification and characterization phases defined by ISO 14044 (ISO 2006). The impact assessment and categories were used to calculate the environmental impact according to ReCipe 2008 v1.05 methodology (midpoint method, hierarchical version) (Goedkoop, 2009). Six impact categories were selected for the study: climate change (CC), photochemical oxidation (POF), terrestrial acidification (TA), freshwater eutrophication (FWE), marine eutrophication (ME) and fossil depletion (FD). Few agricultural or horticultural studies of mineral fertilizer application and its environmental impact on a tomato crop were found in the literature.

\subsubsection{Goal and Scope Definition}

The first step in LCA is to define the goal and scope of the study. Our goal is to compare the agronomic (i.e. yield) and environmental assessment of a tomato crop fertilized with four different doses of nitrogen. Following the ISO (2006), the study's scope included all the stages from cradle to grave involved in the LCA of a horticultural tomato crop. The ISO (2006) defines the functional unit as the unit basis for comparisons between different systems in LCA and the flow unit reference for inputs and outputs of inventories (i.e. energy, water, materials, machinery and equipment). This LCA studied the functional unit's resources and items (i.e. energy and water) consumed per 1 ton of commercial fruit (i.e. tomatoes) per hectare. Similar functional units were found in the literature for expressing inventories and results for horticultural crops in LCA (Martínez et al., 2010; Quirós et al., 2014b; Quirós et al.. 2015). As shown in Figure 1, the system boundaries included the production of mineral fertilizers, transport between the production site and the cultivation plots, and all activities relating to the cultivation phase, which comprised two main stages, i.e. fertirrigation and cultivation management, and the items used in each stage, such as infrastructure, fertilization equipment, machinery and tools, pesticides, irrigation and nursery.

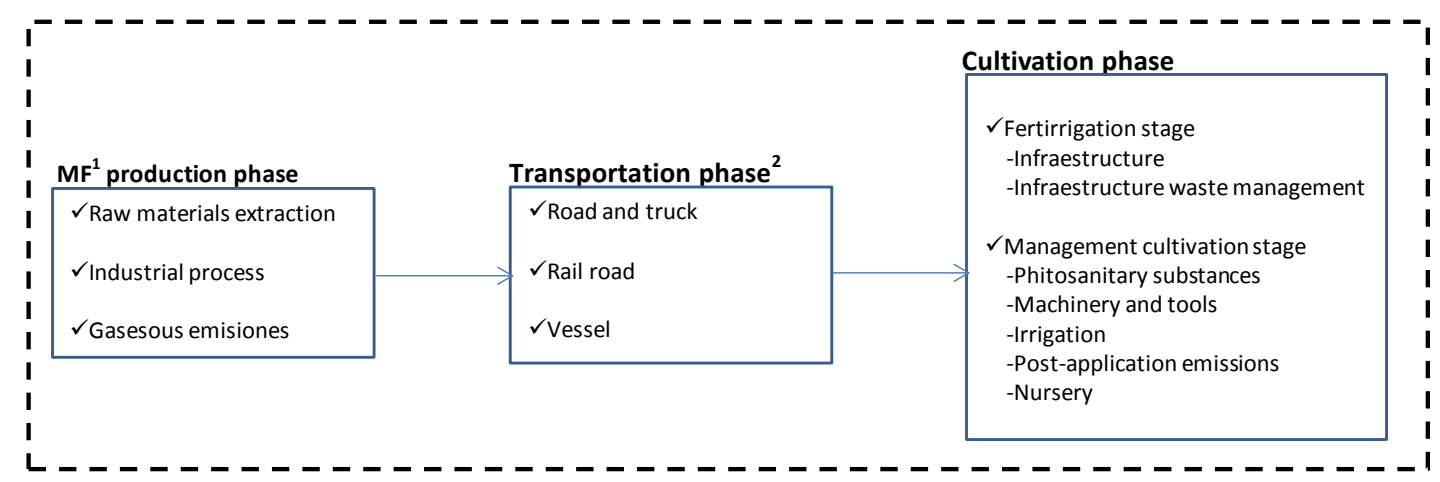

Figure 1. System boundaries

\footnotetext{
${ }^{1}$ MF: Mineral fertilizers

${ }^{2}$ Transportation phase considers construction and vehicle maintenance (Swiss Centre for Life Cycle Inventories, 2016)
} 


\section{Macrothink}

\subsubsection{Quality and Origin of the Data in the Inventory}

Data quality is important when working with complex systems (ISO, 2006). Several sources of data are involved in the study. Data sources for the agronomic and environmental assessment were taken from similar studies by Quirós et al. (2014a, 2014b and 2015). All inventory data for this research were based on these previous studies and adapted from them. As shown in Table 1, most data for inventories were taken from primary sources and few of them from literature references. The main processes and emission factors were taken from the Ecoinvent database v3.0 (Swiss Centre for Life Cycle Inventories, 2016).

Table 1. Data sources for LCA inventories

\begin{tabular}{|c|c|c|c|c|}
\hline Stage & Substages & Substages-processes & Origin & References \\
\hline \multirow[t]{2}{*}{ Mineral fertilizers production } & & Production of $\mathrm{NH}_{3}, \mathrm{NH}_{4} \mathrm{NO}_{3}, \mathrm{KNO}_{3}, \mathrm{~K}_{2} \mathrm{SO}_{4}, \mathrm{KPO}_{4} \mathrm{H}_{2}$ & $\mathrm{DB}^{1}$ & Ecoinvent database v.2.0 \\
\hline & & Doses & $\mathrm{EXR}^{2}$ & Experimental results \\
\hline \multirow[t]{7}{*}{ Mineral fertilizers transport } & & Transport of mineral fertilizers from the plant to the crops and distances & $\mathrm{DB}$ & Ecoinvent database v.2.0 \\
\hline & Fertirrigation & System design & EXR & Experimental results and MAPA 2002 \\
\hline & & Components production and transport & $\mathrm{DB}$ & Ecoinvent database v.2.0 \\
\hline & & Transport and management of waste & DB & Ecoinvent database v.2.0 \\
\hline & Phystosanitary & Types & EXR & Experimental results and MAPA 2002 \\
\hline & & Doses & EXR & Experimental results and MMARMRM 2012 \\
\hline & & Production & $\mathrm{DB}$ & Ecoinvent database v.2.0 \\
\hline \multirow{9}{*}{ Cutivation } & Machinery and tools & Machinery and tools needed & EXR & Experimental results \\
\hline & & Machinery and tools production and maintenance & DB & Ecoinvent database v.2.0 \\
\hline & & Diesel production and emissions & DB-LR ${ }^{3}$ & Ecoinvent database v.2.0 and Gasola et al. 2007 \\
\hline & Irrigation & Water consumption & EXR & Experimental results \\
\hline & & Electricity consumption of pumps & EXR & Experimental results \\
\hline & & Rainfall & LR & Ruralcat 2008 \\
\hline & Fertirrigation emissions & Emissions of $\mathrm{NH} 3, \mathrm{~N} 2 \mathrm{O}, \mathrm{NOx}$ and $\mathrm{N} 2$ to air & LR & Audsley 1997; Bentrup and Küesters 2000 \\
\hline & & Emissions of NO3 to water & LR & Bentrup and Küesters 2000 \\
\hline & Nursery & Greenhouse, irrigation, fertilization, heating and transport & LR & Antón 2005; Matallana and Montero 2001 \\
\hline
\end{tabular}

$\mathrm{EXR}^{2}$ : Experimental Results

$\mathrm{LR}^{3}$ : Literature references

\subsection{Experimental Conditions}

The experimental field was located at the IRTA (Institut de Recerca i Tecnologia Agroalimentàries) research center in Maresme county, municipality of Cabrils in north-east Catalonia (Spain). Maresme county is a region characterized by intensive horticulture (both fruit and vegetables). The tomato crop was grown in a sandy loam soil (i.e. Typic Xerothent). The tomato plants (Lycopersicom esculentum Var. Punxa) were transplanted on May 15, 2012, using a density of 0.8 plants $\mathrm{m}^{-2}$. The tomato crop was harvested on October 3, 2012: a cultivation period of 151 days. The experimental field design consisted of four treatments $(\mathrm{N} 0, \mathrm{~N} 1, \mathrm{~N} 2$ and $\mathrm{N} 3)$ of $42 \mathrm{~m}^{2}$ each. Each treatment had three replicates (126 $\mathrm{m}^{2}$ each), resulting in 12 plots per treatment. The total cultivated area was $504 \mathrm{~m}^{2}$. The plantation was laid out in 4 lines per treatment with a separation of $1.5 \mathrm{~m}$ between lines and $0.9 \mathrm{~m}$ between plants. Following standard practice in the region for 'Penjar' tomato cultivation, a plastic mulch layer was installed, plants were not staked and water was extracted from local wells and delivered via drip irrigation (Castellari, 2016).

\subsection{Weather Conditions}

Climate data were obtained from a weather station next to the field crop. The average annual evapotranspiration during the cultivation period was $633.81 \mathrm{~L} \cdot \mathrm{m}^{-2}$, with $144.3 \mathrm{~L} \cdot \mathrm{m}^{-2}$ rainfall and an average temperature of $20^{\circ} \mathrm{C}$ (Servei Meteorològic de Catalunya, 2016). 


\subsection{Irrigation Water}

To irrigate the tomato crops, we employed the practice that was most common in the region, a drip system using ground water. The amount of water applied in each treatment was measured by meters placed on the plots. The amount of irrigated water was similar for the three treatments, with an average of $106 \mathrm{~L} \cdot \mathrm{m}^{-2}$ per treatment $\left(103.4 \mathrm{~L} \cdot \mathrm{m}^{-2}\right.$ for N0, 110.6 $\mathrm{L} \cdot \mathrm{m}^{-2}$ for $\mathrm{N} 1,107.6 \mathrm{~L} \cdot \mathrm{m}^{-2}$ for $\mathrm{N} 2$ and $102.7 \mathrm{~L} \cdot \mathrm{m}^{-2}$ for $\mathrm{N} 3$ ). The irrigation water had high nitrogen content due to the excessive use of mineral fertilizer in the region (Muñoz et al., 2008). The $\mathrm{NO}^{-3}$ content in the water was counted as nutrient for the fruit. The quantity of $\mathrm{N}$ was considered an input in the inventory measuring environmental impact. Table 2 shows the irrigation water and the $\mathrm{N}$ applied to each treatment.

\subsection{N Applied to Crops}

Plant nutrition is a vital component of crop production and plays an important role in both improving food security and reducing environmental impact. Although $\mathrm{N}$ content in ground water is a potential environmental pollutant, this is a moot question in regions where high concentrations are detected, since $\mathrm{N}$ can be seen as a crop nutrient. In the case study, the concentration of $\mathrm{N}$ in ground water exceeded the limits permitted by the EU. According to Directive 91/676 (European Economic Community, 1991), the high concentration of nitrogen in the ground water (1.86 milli equivalents of $\mathrm{NO}_{3}^{-}=115.32 \mathrm{~g} \mathrm{NO}_{3}^{-} \mathrm{m}^{-3}$ ) near the experimental plots exceeded the permissible limit $\left(50 \mathrm{~g} \mathrm{NO}_{3}^{-} \mathrm{m}^{-3}\right)$. Therefore, the nitrogen concentration in the ground water was taken as a contribution of nutrients to the crops. As shown in Table 2 , the N0 treatment only received $\mathrm{N}$ from irrigation water. In the rest of the treatments, different doses of $\mathrm{N}$ were applied according to the type of mineral fertilizer. The amount of $\mathrm{N}$ was increased at different rates according to the treatment. $\mathrm{N} 1$ was fertilized in a proportion of $49 \% \mathrm{HNO}_{3}$ (nitric acid) and $44 \% \mathrm{NH}_{4} \mathrm{NO}_{3}$ (ammonium nitrate); $\mathrm{N}_{2}$ was fertilized with a proportion of $41 \% \mathrm{HNO}_{3}$ and $54 \% \mathrm{NH}_{4} \mathrm{NO}_{3}$; and $\mathrm{N}_{3}$ was fertilized with a proportion of $35 \% \mathrm{HNO}_{3}$ and $57 \% \mathrm{NH}_{4} \mathrm{NO}_{3}$. The amount of $\mathrm{N}$ applied to all treatments with $\mathrm{KNO}_{3}$ (potassium nitrate) was lower than with the other two inorganic fertilizers (i.e. $\mathrm{HNO}_{3}$ and $\mathrm{NH}_{4} \mathrm{NO}_{3}$ ) (Table 2).

Table 2. $\mathrm{N}$ applied per treatment and type of fertilizer

\begin{tabular}{|c|c|c|c|c|c|}
\hline Treatment / fertilizer & $\begin{array}{l}\mathrm{HNO}_{3}{ }^{1} \\
\left(\mathrm{~kg} \mathrm{~N} \mathrm{ha}^{-1}\right)\end{array}$ & $\begin{array}{l}\mathrm{NH}_{4} \mathrm{NO}_{3}{ }^{2} \\
\left(\mathrm{~kg} \mathrm{~N} \mathrm{ha}^{-1}\right)\end{array}$ & $\begin{array}{l}\mathrm{KNO}_{3}{ }^{3} \\
\left(\mathrm{~kg} \mathrm{~N} \mathrm{ha}^{-1}\right)\end{array}$ & $\begin{array}{l}\text { Irrigation Water } \\
\left(\mathrm{kg} \mathrm{N} \mathrm{ha}^{-1}\right)\end{array}$ & Total \\
\hline NO & 0.00 & 0.00 & 0.00 & 9.27 & 9.27 \\
\hline N1 & 37.69 & 33.97 & 0.88 & 4.53 & 77.06 \\
\hline N2 & 44.66 & 58.70 & 0.90 & 3.84 & 108.10 \\
\hline N3 & 50.94 & 82.77 & 1.43 & 9.45 & 144.59 \\
\hline
\end{tabular}




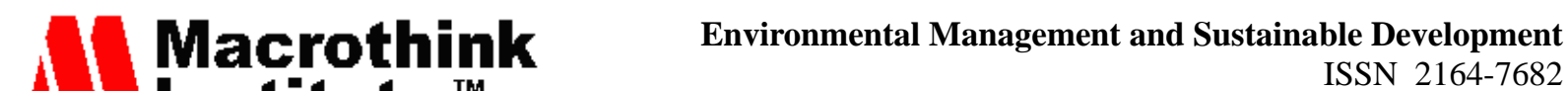 \\ 2019, Vol. 8, No. 3}

\subsection{Life Cycle Inventory (LCI)}

The International Organization for Standardization (ISO, 2006) defines the LCI as the phase in which material and energy flows are compiled and quantified (ISO, 2006). The LCI provides a detailed account of every resource consumption and emission for the whole cycle of the tomato crop. Data in inventory referred to the functional unit for each fertilization treatment (i.e. $\mathrm{kg}$ fruit $\cdot \mathrm{m}^{-2}$ ). All inventory data for the cultivation stage were taken from real experiments directly in the plots (Table 1). The cultivation phase comprised the stages of fertirrigation infrastructure and cultivation management. The fertirrigation infrastructure stage comprised the equipment and ancillary materials for delivering the water, fertilizers and phytosanitary substances to the crop plots. Specifically, a total of twelve equipment and ancillary materials were used for crop fertirrigation, including two pumps for water extraction and irrigation, one water storage tank made of steel and concrete, a fertilizer storage pump, electrovalves for controlling the dosage and a network of pipes for transporting water and fertilizers from the storage tanks to the plot crops. A distance of 1,200 km (round-trip travel) in a 3.5ton van (Swiss Centre for Life Cycle Inventories 2016) from the point of sale (Madrid) to the crop plots (Santa Susana, Barcelona) was assumed for the transport of all the above-mentioned items. All material consumption employs the FU (i.e. $\mathrm{kg}$ fruit $\cdot \mathrm{m}^{-2}$ ) for each fertilization treatment (Table 3).

For the cultivation management stage, the following items were used in the crop area: 1. phytosanitary substances; 2 . the machinery and tools used to prepare the land for cultivation; 3. the water consumed in crop irrigation and the electricity for the well and tank pumps; 4. the post-emissions of cultivation in the field caused by the water and the mineral fertilizer applied; and 5. the nursery sub-stage. Data for this phase (cultivation management) are shown in Table 3.

\subsubsection{Mineral Fertilizer Production and Transport}

The mineral fertilizers were applied with the irrigation water. The doses of mineral fertilizers were calculated by taking into account the soil nutrient content and the agricultural requirements, with the aim of comparing the performance of the four treatments (i.e. yield and impact). The processes for mineral fertilizer production and transport were taken from the Ecoinvent database v2.2 (Swiss Centre for Life Cycle Inventories, 2016). 
Table 3. Inventories per treatment for cultivation phase

\begin{tabular}{|c|c|c|c|c|c|c|c|}
\hline \multirow[b]{2}{*}{ Stages and substages } & \multirow[b]{2}{*}{ Material } & \multirow[b]{2}{*}{ Lifespan } & \multirow[b]{2}{*}{ Units $\cdot \mathrm{FU}^{-1}$} & \multicolumn{4}{|c|}{ Amounts per functional unit (FU) } \\
\hline & & & & N0 & $\mathrm{N} 1$ & $\mathrm{~N} 2$ & $\mathrm{~N} 3$ \\
\hline Functional Unit $\left(\mathrm{kg} \mathrm{m}^{-2}\right)$ & & & & $2.95 \mathrm{E}+00$ & $5.50 \mathrm{E}+00$ & $4.40 \mathrm{E}+00$ & $3.50 \mathrm{E}+00$ \\
\hline \multicolumn{8}{|l|}{ 1.1 Equipment and tools } \\
\hline Water irrigation pump & Steel & 20 years & $\mathrm{kg}$ & $5.91 \mathrm{E}-03$ & $3.17 \mathrm{E}-03$ & $3.96 \mathrm{E}-03$ & $4.98 \mathrm{E}-03$ \\
\hline Water storage tank & Concrete & 50 years & $\mathrm{m} 3$ & $1.19 \mathrm{E}-01$ & $1.07 \mathrm{E}-03$ & $1.34 \mathrm{E}-03$ & $1.69 \mathrm{E}-03$ \\
\hline Fertilizer storage tank & LDPE & 10 years & $\mathrm{kg}$ & $5.32 \mathrm{E}-02$ & $2.85 \mathrm{E}-02$ & $3.57 \mathrm{E}-02$ & 4.48E-02 \\
\hline Electrovalves & LDPE & 10 years & $\mathrm{kg}$ & $1.66 \mathrm{E}-03$ & $8.89 \mathrm{E}-04$ & $1.11 \mathrm{E}-03$ & $1.40 \mathrm{E}-03$ \\
\hline Primary pipes & LDPE & 10 years & $\mathrm{kg}$ & 2.39E-02 & $1.28 \mathrm{E}-02$ & $1.60 \mathrm{E}-02$ & $2.02 \mathrm{E}-02$ \\
\hline $1.2 \mathrm{~W}$ aste management & & & $\mathrm{g}$ & $3.39 \mathrm{E}+02$ & $1.82 \mathrm{E}+02$ & $2.27 \mathrm{E}+02$ & $2.86 \mathrm{E}+02$ \\
\hline \multicolumn{8}{|l|}{ 2.Cultivation_management stage } \\
\hline 2.1 Pesticides & & & $\mathrm{kg}$ & $6.62 \mathrm{E}-01$ & $3.55 \mathrm{E}-01$ & 4.44E-01 & $5.58 \mathrm{E}-01$ \\
\hline \multicolumn{8}{|l|}{ 2.2 Machinery and tools } \\
\hline Tractor & & $7200 \mathrm{~h}$ & $\mathrm{~kg}$ & $9.18 \mathrm{E}-02$ & 4.93E-02 & $6.16 \mathrm{E}-02$ & 7.74E-02 \\
\hline Diesel consumption & & & $\mathrm{kg}$ & $6.61 \mathrm{E}+00$ & $3.54 \mathrm{E}+00$ & $4.43 \mathrm{E}+00$ & $5.57 \mathrm{E}+00$ \\
\hline Plough & & $300 \mathrm{~h}$ & $\mathrm{~kg}$ & $5.87 \mathrm{E}-02$ & $3.15 \mathrm{E}-02$ & $3.94 \mathrm{E}-02$ & 4.95E-02 \\
\hline Furrow opener & & $1190 \mathrm{~h}$ & $\mathrm{~kg}$ & $5.18 \mathrm{E}-02$ & $2.78 \mathrm{E}-02$ & $3.47 \mathrm{E}-02$ & 4.36E-02 \\
\hline Spray bag & & $1000 \mathrm{~h}$ & $\mathrm{~kg}$ & $1.53 \mathrm{E}-02$ & $8.21 \mathrm{E}-03$ & $1.03 \mathrm{E}-02$ & $1.29 \mathrm{E}-02$ \\
\hline Ancillary equipment & & & $\mathrm{kg}$ & $3.11 \mathrm{E}-01$ & $1.67 \mathrm{E}-01$ & $2.08 \mathrm{E}-01$ & 2.62E-01 \\
\hline 2.4 Nursery plant & & & & $2.69 \mathrm{E}+02$ & $9.09 \mathrm{E}+01$ & $1.14 \mathrm{E}+02$ & $1.43 \mathrm{E}+02$ \\
\hline
\end{tabular}

\section{Results}

\subsection{Yield and Quality Parameters of Fruits}

Table 4 shows the total and commercial yield and the quality parameters of fruits for the different treatments applied to the tomato crop. The values represent the median values for the four treatments. To identify differences in values, data were analyzed with the SAS Enterprise Guide (SAS Institute, Inc., Cary, NC USA, 2006, version 3.0.2). Median values were statistically analyzed with the Fisher test for $95 \%$ confidence. Some significant statistical differences ( $\mathrm{P}$ value $<95 \%$ ) were observed among treatments for total and commercial yields (Table 4). The agronomical results (i.e. yield) showed that NO had the lowest total and commercial yield. Although the soil acts as a repository of nutrients, the crop has to be supplied with a certain quantity of nutrients $(\mathrm{N})$ to increase the fruit yield. We found that N1 had the highest yield, which was $76 \%$ higher than the lowest yield (i.e. 34.6 ton $\cdot$ ha $^{-1}$ for N0) and $18 \%$ higher than the second-best yield found (i.e. 51.8 ton $\cdot \mathrm{ha}^{-1}$ for N2). The same trend was observed for the commercial yield as for the total yield. The harvests were within the normal values expected for the total and commercial production of tomatoes in the area (Muñoz et al., 2007a; Muñoz et al., 2007b). For this experiment, these results 
demonstrate that more $\mathrm{N}$ (Table 2) given to a crop does not necessarily mean a higher fruit yield in either of the two agronomical parameters (i.e. total and commercial yield). The effect of nitrogen on yield showed a linear regression that stagnates at a certain point and may even be negative for the crop (i.e. phytotoxic effect) (Castellari, 2016). As well as for yield, some significant statistical differences were observed for the quality parameters analyzed (i.e. weight, diameter and ${ }^{\circ}$ Brix) (Table 4). Results showed that there is no trend for the three quality parameters measured: N0 had the greatest value for weight, $44 \%$ more than the lowest value (N3); and N0 was 17\% higher than the lowest value observed (N3) for the diameter. However, in the case of ${ }^{\circ}$ Brix, the greatest value was with $\mathrm{N} 2$, which was $19 \%$ higher than the lowest value (N1). Although N0 had the lowest yield, the greatest diameter and weight of fruit were with N0 (Table 4). Differences observed in the quality parameters can be attributed to the randomness of the experiment. Several variables, such as soil, crop type, weather conditions, temperature or type of fertilizer, determine the quality parameters, along with other characteristics related to the crop, for example, crop yield and the rate of nitrogen mineralization in soil, among others. Quirós. (2014) pointed out that the N mineralization of organic fertilizers depends on complex interrelations of variables such as soil type, crop management, weather, temperature, etc.

Table 4. Total and commercial yield and quality parameters of tomatoes

\begin{tabular}{llllll}
\hline Treatment & $\begin{array}{l}\text { Total yield } \\
\left(\text { ton } \cdot \mathrm{ha}^{-1}\right)\end{array}$ & $\begin{array}{l}\text { Commercial } \\
\text { yield } \\
\left(\text { ton } \cdot \mathrm{ha}^{-1}\right)\end{array}$ & Weight $(\mathrm{kg})$ & $\begin{array}{l}\text { Diameter } \\
(\mathrm{cm})\end{array}$ & ${ }^{\circ}$ Brix \\
\hline N0 & $34.6^{\mathrm{b}}$ & $29.5^{\mathrm{b}}$ & $63.48^{\mathrm{a}}$ & $4,86^{\mathrm{a}}$ & $7.2^{\mathrm{bc}}$ \\
N1 & $61.0^{\mathrm{a}}$ & $55.0^{\mathrm{a}}$ & $61.93^{\mathrm{a}}$ & $4.82^{\mathrm{a}}$ & $6.8^{\mathrm{a}}$ \\
N2 & $51.8^{\mathrm{ab}}$ & $44.0^{\mathrm{ab}}$ & $52.68^{\mathrm{b}}$ & $4.40^{\mathrm{ab}}$ & $8.1^{\mathrm{a}}$ \\
$\mathrm{N} 3$ & $47.3^{\mathrm{a}}$ & $35.0^{\mathrm{a}}$ & $44.14^{\mathrm{b}}$ & $4.25^{\mathrm{b}}$ & $7.7^{\mathrm{ab}}$ \\
\hline
\end{tabular}

Different letters mean that there are significant differences for a $\mathrm{P}$ value of $\mathrm{p}<0.05$

\subsection{Environmental Assessment by Category, Phases, Stages and Items}

To facilitate the environmental assessment for each fertilization treatment, the horticultural systems were split into stages and explained by impact category, fertilization treatment and phases (Table 5).

Climate Change (CC) or Global Warming Potential over 100 years is defined as the impact that human emissions have on the radiative forcing of the atmosphere (i.e. heat radiation), which is best known as the greenhouse effect (IPCC 2006). The same trend for CC was observed for the four fertilization treatments (i.e. N0, N1, N2 and N3), in which cultivation management was the main contributor, followed by mineral fertilizer production and the fertirrigation phase. Impact values varied for each phase according to the fertilization treatment (Table 5, Figure 2). CC varied from $62 \%$ for NO, the highest value observed, to $44 \%$ for N3, which was the lowest value observed. Two items in cultivation management were the main CC contributors: machinery and tools, and irrigation. The former's impact was due to the use of diesel to operate the machinery; and the latter's was due to the electricity used to 
pump water to crops.

Photochemical Oxidation Potential (POP) behaved like CC: the cultivation phase was the highest contributor in all treatments assessed, the values ranging from $72 \%$ for N0 to $64 \%$ for N2 and N3, which were the lowest values in this category (Figure 2 and Table 5). The second main contributor phase for POP and for all fertilization treatments was fertilizer production and transport. The contributions in this phase ranged from $28 \%$ for N3, the highest value, to $23 \%$ for N0, the lowest. The impact for this category correlated directly with the quantity of mineral fertilizer applied to crops. In our case study, the quantity of nutrient (i.e. mineral fertilizer) applied was increased slightly for each treatment (Table 2).

For the third category studied, terrestrial acidification (TA), mineral fertilizer production was the main contributor in all fertilization treatments. Acidification refers to processes that increase the acidity of water and soil systems (Arena et al., 2003). Emissions of potentially acidifying substances $\left(\mathrm{NO}_{\mathrm{x}}, \mathrm{SO}_{\mathrm{x}}, \mathrm{NH}_{3}, \mathrm{HCL}\right.$, etc.) lead to deposition, which in turn may lead to damage to animal and plant populations. In our case study, the contributions for this category (TA) varied from the highest contribution of $53 \%$ for $\mathrm{N} 3$ to the lowest contribution of $47 \%$ for N0 (Table 5 and Figure 3). For POP too, the level of impacts varied according to the quantity of mineral fertilizer applied to each treatment. The second phase with most impact in this category (TA) was cultivation management, in which electricity to pump water from wells and to crops and the diesel consumed by the machinery (i.e. tractors and agricultural machinery) to prepare the plots were the items contributing most.

Eutrophication is a phenomenon that affects terrestrial as well as aquatic ecosystems. Nitrogen (N) and phosphorus (P) are the two nutrients most involved in eutrophication (Bauman and Tillman 2004). The former affects the nutrient source in marine ecosystems, as the latter does in freshwater ecosystems. In terms of environmental impact, these are called Marine Eutrophication (ME) and Freshwater Eutrophication (FWE), respectively. As seen in Figure 2 and Table 5, the impact value (\%) for the highest impact contributor (i.e. cultivation management) for FWE was very similar for the four fertilization treatments: in all cases, the contribution impact values were between $72 \%$ to $74 \%$ depending on the treatment. Irrigation was the stage that most contributed to this phase (i.e. cultivation management). As mentioned above, emissions of $\mathrm{P}$ relating to the production process or post-cultivation emissions to soil had most impact in this category (Figure 3). Likewise, the results (Table 5 and Figure 3) show that mineral fertilizers are another strong source of $\mathrm{P}$ emissions during the production process.

For the ME category, cultivation management was the phase that most contributed in the four fertilization treatments assessed (Table 5 and Figure 2). Very similar impact values were observed for all fertilization treatments. The contribution values of this phase ranged from $51 \%$ for $\mathrm{N} 3$, the highest value, to $62 \%$ for N0, the lowest value. Likewise, fertirrigation was the stage that most contributed in the cultivation phase. Master Bi biodegradable plastic was the item that most affected the fertirrigation stage.

For the Fossil Depletion (FD) category, cultivation management was the phase that had the highest contribution in all the fertilization treatments studied. The contribution of impact 
values for this phase ranged from $50 \%$ for N3, the lowest value, to $56 \%$ for N0, the highest (Table 5 and Figure 2). Depending on the fertilization treatment, the stages that most contributed in the cultivation management phase were fertirrigation, machinery and tools, and irrigation (Figure 3). For cultivation management, the secondary pipe used to transport water from the storage tank to crop and Master Bi biodegradable plastic were the items that most contributed in this phase. The diesel consumed to operate the agricultural machinery that prepared the plots was the item that most contributed in this stage (i.e. machinery and tools); and for the irrigation stage, the pump used to irrigate the crop was the item that most contributed.

Overall, N1 was the horticultural system (i.e. treatment) that showed the best environmental performance in all the categories studied. $\mathrm{N} 2$ had the second best environmental performance, except for the CC category, in which N0 showed slightly better impact values than N2. The $\mathrm{N} 3$ system had the worst environmental performance, with the highest impact values in all categories assessed.
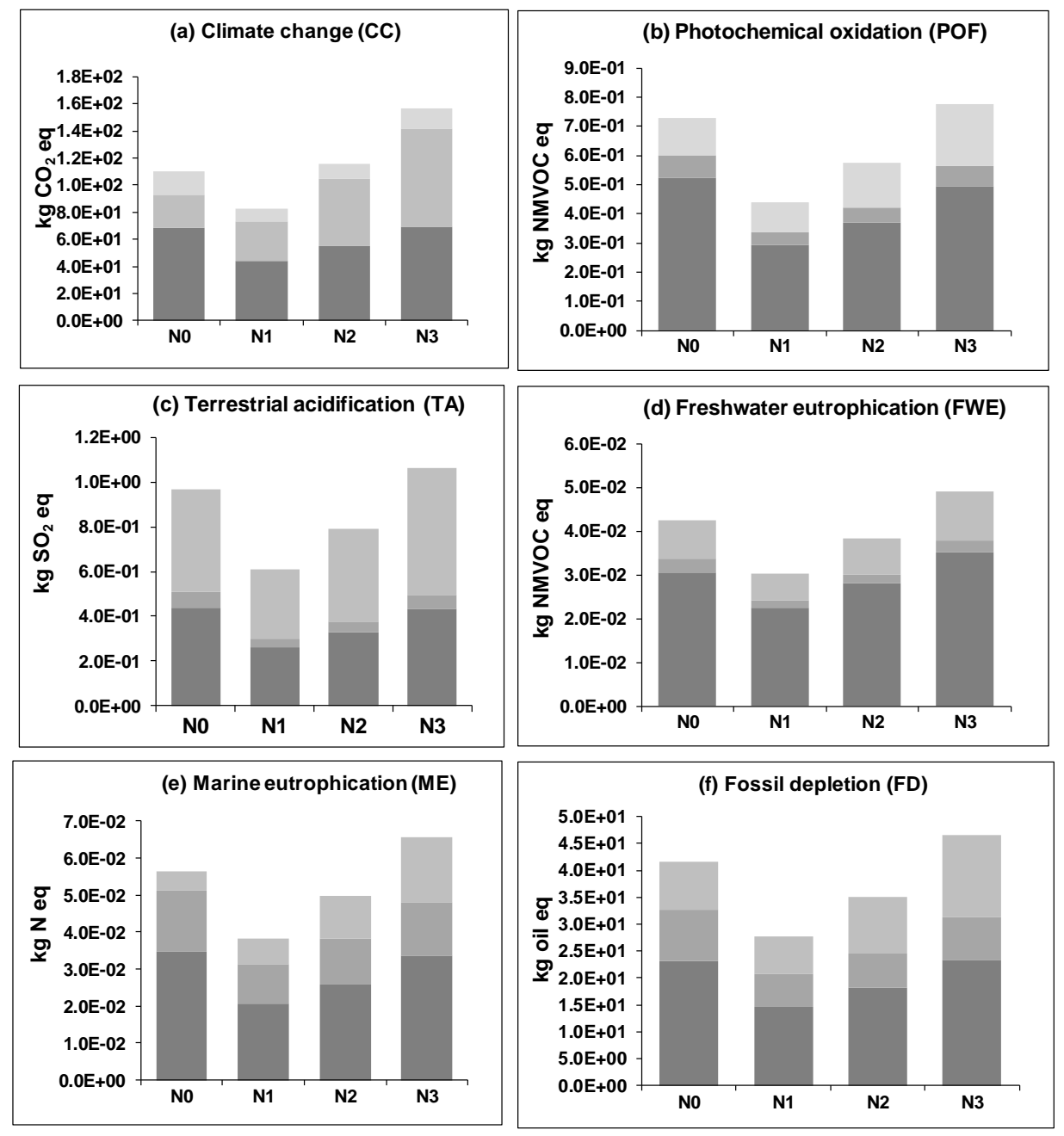

Cultivation management

Mineral fertilizer production and transport

Fertirrigation

Figure 2. Impact per fertilization treatment, category and stages 


\section{Macrothink}

Environmental Management and Sustainable Development

ISSN 2164-7682

2019, Vol. 8, No. 3
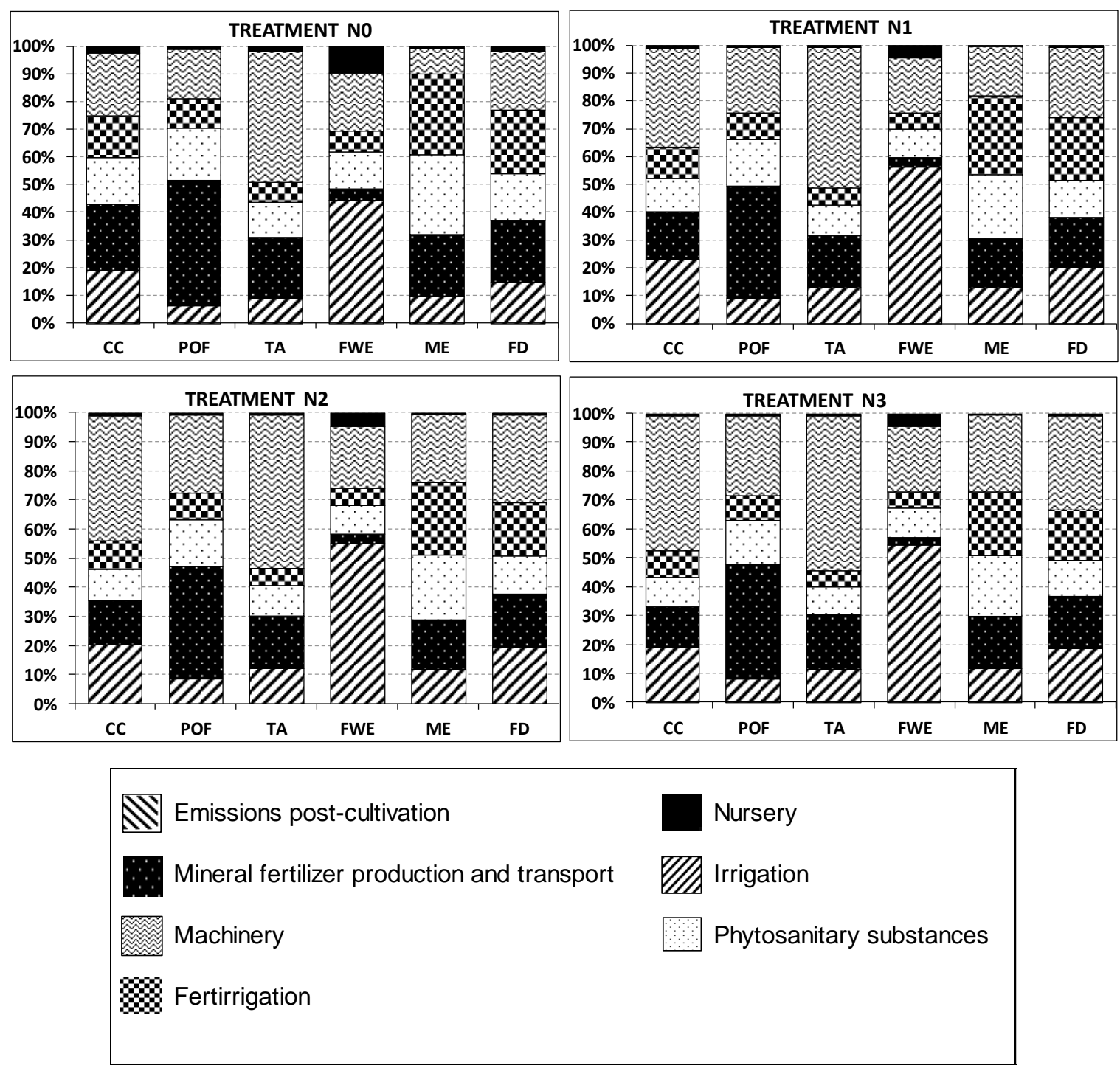

CC: Climate Change

POF: Photochemical Oxidation Formation TA: Terrestrial Acidification

FWE: Freshwater Eutrophication ME: Marine Eutrophication

FD: Fossil Depletion

Figure 3. Impact per fertilization treatment and elements 
Table 5. Total Impact per fertilization treatment, impact category, phases and stages

\begin{tabular}{|c|c|c|c|c|c|c|c|c|}
\hline \multicolumn{9}{|c|}{ Fertilization treatment and categories } \\
\hline NO & Units & Total impacts & $\begin{array}{l}\mathrm{MF}^{1} \\
\text { production } \\
\text { and transport }\end{array}$ & $\%$ & Fertirrigation & $\%$ & $\begin{array}{l}\text { Cultivation } \\
\text { management }\end{array}$ & $\%$ \\
\hline $\mathrm{CC}^{2}$ & $\mathrm{~kg} \mathrm{CO}$ eq. & $1.10 \mathrm{E}+02$ & $2.50 \mathrm{E}+01$ & $23 \%$ & $1.68 \mathrm{E}+01$ & $15 \%$ & $6.83 \mathrm{E}+01$ & $62 \%$ \\
\hline $\mathrm{POP}^{3}$ & kg NMVOC eq. & 7.27E-01 & $1.28 \mathrm{E}-01$ & $18 \%$ & $7.78 \mathrm{E}-02$ & $11 \%$ & $5.22 \mathrm{E}-01$ & $72 \%$ \\
\hline $\mathrm{TA}^{4}$ & $\mathrm{~kg} \mathrm{SO}_{2}$ eq. & $9.66 \mathrm{E}-01$ & 4.57E-01 & $47 \%$ & 6.97E-02 & $7 \%$ & 4.39E-01 & $45 \%$ \\
\hline FWE $^{5}$ & kg $P$ eq. & 4.25E-02 & 8.83E-03 & $21 \%$ & $3.24 \mathrm{E}-03$ & $8 \%$ & 3.04E-02 & $72 \%$ \\
\hline $\mathrm{ME}^{5}$ & $\mathrm{~kg} \mathrm{~N}$ eq. & 5.64E-02 & 5.16E-03 & $9 \%$ & 1.64E-02 & $29 \%$ & 3.49E-02 & $62 \%$ \\
\hline $\mathrm{FD}^{6}$ & $\mathrm{~kg}$ oil eq. & $4.16 \mathrm{E}+01$ & $8.92 \mathrm{E}+00$ & $21 \%$ & $9.48 \mathrm{E}+00$ & $23 \%$ & $2.32 E+01$ & $56 \%$ \\
\hline \multicolumn{9}{|l|}{ N1 } \\
\hline $\mathrm{CC}$ & kg CO${ }_{2}$ eq. & $8.24 \mathrm{E}+01$ & $2.94 \mathrm{E}+01$ & $36 \%$ & $9.25 E+00$ & $11 \%$ & $4.38 \mathrm{E}+01$ & $53 \%$ \\
\hline POP & kg NMVOC eq. & 4.41E-01 & 1.04E-01 & $24 \%$ & 4.22E-02 & $10 \%$ & $2.95 \mathrm{E}-01$ & $67 \%$ \\
\hline TA & $\mathrm{kg} \mathrm{SO} \mathrm{S}_{2}$ eq. & $6.09 \mathrm{E}-01$ & 3.07E-01 & $51 \%$ & 3.74E-02 & $6 \%$ & 2.64E-01 & $43 \%$ \\
\hline FWE & kg $P$ eq. & 3.03E-02 & $6.01 \mathrm{E}-03$ & $20 \%$ & 1.74E-03 & $6 \%$ & 2.25E-02 & $74 \%$ \\
\hline ME & kg N eq. & 3.82E-02 & $6.73 \mathrm{E}-03$ & $18 \%$ & 1.09E-02 & $28 \%$ & $2.06 \mathrm{E}-02$ & $54 \%$ \\
\hline FD & kg oil eq. & 2.77E+01 & $7.04 \mathrm{E}+00$ & $25 \%$ & $6.18 \mathrm{E}+00$ & $22 \%$ & $1.45 \mathrm{E}+01$ & $52 \%$ \\
\hline \multicolumn{9}{|l|}{ N2 } \\
\hline CC & $\mathrm{kg} \mathrm{CO}_{2}$ eq. & $1.16 \mathrm{E}+02$ & $4.96 \mathrm{E}+01$ & $43 \%$ & $1.14 \mathrm{E}+01$ & $10 \%$ & $5.48 \mathrm{E}+01$ & $47 \%$ \\
\hline POP & kg NMVOC eq. & 5.75E-01 & 1.54E-01 & $27 \%$ & $5.24 \mathrm{E}-02$ & $9 \%$ & 3.69E-01 & $64 \%$ \\
\hline TA & $\mathrm{kg} \mathrm{SO}$ eq. & 7.91E-01 & 4.14E-01 & $52 \%$ & 4.68E-02 & $6 \%$ & 3.30E-01 & $42 \%$ \\
\hline FWE & kg $P$ eq. & 3.84E-02 & $8.21 \mathrm{E}-03$ & $21 \%$ & 2.17E-03 & $6 \%$ & 2.80E-02 & $73 \%$ \\
\hline ME & kg N eq. & 4.98E-02 & $1.16 \mathrm{E}-02$ & $23 \%$ & $1.24 \mathrm{E}-02$ & $25 \%$ & 2.57E-02 & $52 \%$ \\
\hline FD & $\mathrm{kg}$ oil eq. & $3.50 \mathrm{E}+01$ & $1.05 \mathrm{E}+01$ & $30 \%$ & $6.37 \mathrm{E}+00$ & $18 \%$ & $1.82 \mathrm{E}+01$ & $52 \%$ \\
\hline \multicolumn{9}{|l|}{ N3 } \\
\hline $\mathrm{CC}$ & $\mathrm{kg} \mathrm{CO}$ eq. & $1.56 \mathrm{E}+02$ & $7.30 \mathrm{E}+01$ & $47 \%$ & $1.44 \mathrm{E}+01$ & $9 \%$ & $6.89 \mathrm{E}+01$ & $44 \%$ \\
\hline POP & kg NMVOC eq. & 7.78E-01 & 2.15E-01 & $28 \%$ & $6.72 \mathrm{E}-02$ & $9 \%$ & 4.96E-01 & $64 \%$ \\
\hline TA & $\mathrm{kg} \mathrm{SO}_{2}$ eq. & $1.06 \mathrm{E}+00$ & 5.69E-01 & $53 \%$ & 5.96E-02 & $6 \%$ & 4.35E-01 & $41 \%$ \\
\hline FWE & kg P eq. & 4.90E-02 & 1.11E-02 & $23 \%$ & 2.75E-03 & $6 \%$ & 3.51E-02 & $72 \%$ \\
\hline ME & kg N eq. & $6.55 \mathrm{E}-02$ & $1.74 \mathrm{E}-02$ & $27 \%$ & $1.45 \mathrm{E}-02$ & $22 \%$ & 3.36E-02 & $51 \%$ \\
\hline $\mathrm{FD}$ & kg oil eq. & $4.65 \mathrm{E}+01$ & $1.52 \mathrm{E}+01$ & $33 \%$ & $8.06 \mathrm{E}+00$ & $17 \%$ & $2.33 \mathrm{E}+01$ & $50 \%$ \\
\hline \multicolumn{9}{|c|}{${ }^{1}$ MF: Mineral Fertilizer } \\
\hline \multicolumn{9}{|c|}{${ }^{2} \mathrm{CC}$ : Climate Change } \\
\hline \multicolumn{9}{|c|}{${ }^{3} \mathrm{POP}:$ Pothochemical Oxidantion Potential } \\
\hline \multicolumn{9}{|c|}{${ }^{4} \mathrm{TA}:$ Terrestrial Acidification } \\
\hline \multicolumn{9}{|c|}{${ }^{5} \mathrm{FWE}$ : Freshwater Eutrophication } \\
\hline \multicolumn{9}{|c|}{${ }^{6} \mathrm{ME}:$ Marine Eutrophication } \\
\hline${ }^{7} \mathrm{FD}: \mathrm{F}$ & & & & & & & & \\
\hline
\end{tabular}

\section{Conclusions}

Four horticultural treatments of a tomato crop were assessed to study their agronomical (i.e. yield and quality parameters) and environmental performance. LCA methodology was used to observe the environmental performance for the horticultural systems throughout the entire life cycle. To show the effect of nutrients on fruit yields, the systems were fertilized with different doses of $\mathrm{N}$. In all treatments, the fertilizers were applied to crops with a drip irrigation system. Comparison of the four fertilization treatments demonstrated that, for this experiment, the best yield was for the N1 treatment, and that the best environmental 
performance in all categories assessed was also for N1. For all treatments, cultivation was the phase that most contributed in all impact categories. Depending on the impact category, several items affected environmental performance. For example, irrigation, mineral fertilizer production and transport, and machinery and tools were the items contributing most at each stage. Energy consumption (i.e. diesel and electricity) to operate a tractor and agricultural machinery and electricity used to pump water from wells to crops had a significant impact on the systems. Finally, we conclude that greater amounts of fertilizer do not necessarily mean a greater yield. This relevant outcome is very important for decision-makers, as it contributes to environmental sustainability, and so to the well-being of society.

\section{Acknowledgements}

This study was supported by the Departament d'Agricultura de Ramaderia i Pesca (DARP) of the Generalitat de Catalunya. We want to thank the Instituto de Investigación en Tecnologías Agroalimentarias de Catalunya (IRTA) for support in developing the environmental and agronomical assessment of the crop. We also want to thank the Escuela de Ingeniería Industrial and the Vicerrectoría de Investigación de Acción Social of the Universidad de Costa Rica for their approval of the project.

\section{References}

Arena, U., Mastellone, M., \& Perugini, F. (2003). The environmental performance of alternative solid waste management options: a life cycle assessment study. Chemical Engineering Journal, 96(1-3), 207-222. https://doi.org/10.1016/j.cej.2003.08.019

Bach, M., \& Becker, R. (1995). Regional differenzierte Abschätzung des Nitrateintrages aus diffusen Quellen in das Grundwasser- Untersuchung für die Bundesrepublik (Regionally differentiated estimation of nitrate immissions to groundwater from non-point sources-investigations in Germany). Institut für Landeskultur, University of Gießen.BfN

Baumann, H., \& Tillman, A.-M. (2004). The Hitch Hiker's Guide to LCA. Studentlitteratur Lund.

Boye, J. I., \& Arcand, Y. (2013). Current Trends in Green Technologies in Food Production and Processing. Food Engineering Reviews. https://doi.org/10.1007/s12393-012-9062-z

Brentrup, F., Küsters, J., Kuhlmann, H., \& Lammel, J. (2004). Environmental impact assessment of agricultural production systems using the life cycle assessment methodology: I. Theoretical concept of a LCA method tailored to crop production. European Journal of Agronomy, 20(3), 247-264. https://doi.org/10.1016/S1161-0301(03)00024-8

Castellari, M., Seda, M., Sarraga, C., Montero, J. I., \& Castellari, M. (2016). Municipal solid waste composting : Application as a tomato fertilizer and its effect on crop yield, fruit quality and phenolic content. Renewable Agriculture and Food Systems.

http://dx.doi.org/10.1017/S1742170516000296

Colla, G., Battistelli, A., Moscatello, S., Proietti, S., \& Saccardo, F. (2003). Produzione e caratteristiche qualitative di ibridi di pomodoro da industria in relazione alla fertirrigazione 
azotata. Italus Hortus, 10(6), 34-42.

CREA, (2005). Centro Regional de Estudios del Agua, Universidad de Castilla de la Mancha. Hoja Informativa No 11.

Dadomo, M., Gainza, A. M., Dumas, Y., Bussières, P., Macua, J. L., Christou, M., \& Branthôme, X. (1994). Influence of water and nitrogen availability on yield components of processing tomato in the European Union countries. Acta Horticulturae, 376, 271-274. https://doi.org/10.17660/ActaHortic.1994.376.33

Dorais, M., Ehret, D. L., \& Papadopoulos, A. P. (2008). Tomato (Solanum lycopersicum) health components: From the seed to the consumer. Phytochemistry Reviews, 7(2), 231-250. https://doi.org/10.1007/s11101-007-9085-x

ECETOC, (1994). Ammonia Emissions to Air in Western Europe. European Chemical Industry Ecology and Toxicology Centre, Brussels, Belgium: 62.

ECETOC. (1988). Nitrate and drinking water. European Chemical Industry Ecology and Toxicology Centre, Brussels, Belgium: 27.

Engels, T. (1993). Nitratauswaschung aus Getreide- und Zucker- rübenflächen bei unterschiedlichem N-Angebot (Nitrate leaching from cereal and sugar beet fields at different levels of $\mathrm{N}$ supply). $\mathrm{PhD}$ thesis, University of Hanover.

European Economic Community, (1991). Directive 91/676/ECC, of 12 December 1991 concerning the protection of waters against pollution caused by nitrates from agricultural sources. Off. J. Eur. Commun. 21, L327.

Eurostat. Fertilizers consumed in EU-27for 2010, (2012). Statistics. European Commission. [Online] Available: http://epp.eurostat.ec.europa.eu/portal/page/portal/eurostat/home

Food and Agriculture Organization of the United Nations (FAO). (2003. World agriculture: Towards 2015/2030, an FAO perspective . London: Earthscan Publications Ltd.

Goedkoop, M., Heijungs, R., De Schryver, A., Struijs, J., \& van Zelm, R. (2013). ReCiPe 2008. A LCIA method which comprises harmonised category indicators at the midpoint and the endpoint level. Characterisation. A Life Cycle Impact ....: 133.

International Organization for Standardisation. (2006). ISO 1440 Environmental management-life cycle assessment-principles and framework. London: British Standards Institution.

IPCC. (2006). 2006 IPCC Guidelines for National Greenhouse Gas Inventories Volume 4 Agriculture, Forestry and Other Land Use Chapter 4 forest land 2006. Forestry, 4(2), 1-29. [Online] Available:

http://www.ipcc-/public/2006gl/pdf/4_Volume4/V4_04_Ch4_Forest_Land.pdf

Iqbal, M., Niamatullah, M., Yousaf, I., Munir, M., \& Khan, M. Z. (2011). Effect of Nitrogen and Potassium on Growth. Economical Yield and Yield Components of Tomato Citation, 27(4), 16-19. 
Kaniszewski, S., Elkner, K., \& Rumpel, J. (1987). Effect of nitrogen fertilization on yield, nitrogen status in plants and quality of fruits of direct seeded tomatoes. Acta Horticulturae, 200, 195-202. https://doi.org/10.17660/ActaHortic.1987.200.18

Kooner, K. S., \& Randhawa, K. S. (1990). Effect of varying levels and sources of nitrogen on yield and processing qualities of tomato varieties. Acta Horticulturae, 267, 120-124. https://doi.org/10.17660/ActaHortic.1990.267.11

Martínez-Blanco, J., Antón, A., Rieradevall, J., Castellari, M., \& Muñoz, P., (2010). Comparing nutritional value and yield as functional units in the environmental assessment of horticultural production with organic or mineral fertilization. Int. J. Life Cycle Assess, 16, 12-26.

Martínez-Blanco, J., Antón, A., Rieradevall, J., Castellari, M., \& Muñoz, P. (2010). Comparing nutritional value and yield as functional units in the environmental assessment of horticultural production with organic or mineral fertilization. The International Journal of Life Cycle Assessment, 16(1), 12-26. https://doi.org/10.1007/s11367-010-0238-6

Muñoz, P., Anton, A., Nuñez, M., Paranjpe, A., Ariño, J., Castells, X., Montera, J. I., \& Rieradevall, J. (2008). Comparing the environmental impacts of greenhouse versus open-field tomato production in the Mediterranean region. In Acta Horticulturae, 801 PART, 2, 1591-1596. https://doi.org/10.17660/ActaHortic.2008.801.197

Muñoz, P., Antón, A., Paranjpe, A., Ariño, J., \& Montero, J. I. (2008). High decrease in nitrate leaching by lower $\mathrm{N}$ input without reducing greenhouse tomato yield. Agronomy for Sustainable Development, 28, 489-495. https://doi.org/10.1051/agro:2008024

Muñoz, P., Antón, A., Vijay, A., Montero, J., Ariño, J., Rodríguez, D., \& Castells, X. (2007b). Producción de tomate en la comarca del Maresme con diferentes soluciones nutritivas (in Spanish). In: (Ed.), XXXVII Seminario de Tècnicos y Especialistas en Horticultura. Almería (España). In press

Parisi, M., Giordano, L., Pentangelo, A., D’Onofrio, B., \& Villari, G. (2006). Effects of Different Levels of Nitrogen Fertilization on Yield and Fruit Quality in Processing Tomato. Acta Horticulturae, 700, 129-132. https://doi.org/10.17660/ActaHortic.2006.700.19

PRé Consultants, (2011). SimaPro Software Versión 7.3.2. PRé Consultants, The Netherlands.

Quirós, R., Villalba, G., Gabarrell, X., \& Muñoz, P. (2015). Life cycle assessment of organic and mineral fertilizers in a crop sequence of cauliflower and tomato. International Journal of Environmental Science and Technology, 12(10), 3299-3316.

https://doi.org/10.1007/s13762-015-0756-7

Quirós, R., Villalba, G., Muñoz, P., Colón, J., Font, X., \& Gabarrell, X. (2014). Environmental assessment of two home composts with high and low gaseous emissions of the composting process. Resources, Conservation and Recycling.

https://doi.org/10.1016/j.resconrec.2014.05.008

Quirós, R., Villalba, G., Muñoz, P., Font, X., \& Gabarrell, X. (2014b). Environmental and 


\section{Macrothink \\ Environmental Management and Sustainable Development \\ ISSN 2164-7682 \\ 2019, Vol. 8, No. 3}

agronomical assessment of three fertilization treatments applied in horticultural open field crops. Journal of Cleaner Production, 67, 147-158.

https://doi.org/10.1016/j.jclepro.2013.12.039

Servei Meteorològic de Catalunya, (2016). Serveis i dades climàtiques. [Online] Available: http://www.meteo.cat/wpweb/climatologia/serveis-i-dades-climatiques

Skowrońska, M., \& Filipek, T. (2014). Life cycle assessment of fertilizers: a review. International Agrophysics, 28(1), 101-110. https://doi.org/10.2478/intag-2013-0032

Sommer, S. G. (1992). Ammonia volatilization from cattle and pig slurry during storage and after application in the field. $\mathrm{PhD}$ thesis, University of Copenhagen.

\section{Copyright Disclaimer}

Copyright for this article is retained by the author(s), with first publication rights granted to the journal.

This is an open-access article distributed under the terms and conditions of the Creative Commons Attribution license (http://creativecommons.org/licenses/by/3.0/). 